\title{
Excess production of phage $\lambda$ delayed early proteins under conditions supporting high Escherichia coli growth rates
}

\author{
Magdalena Gabig, ${ }^{1}$ Michał Obuchowski, ${ }^{1}$ Alicja Węgrzyn, ${ }^{2}$ \\ Agnieszka Szalewska-Pałasz, ${ }^{1}$ Mark S. Thomas ${ }^{3}$ and Grzegorz Węgrzyn ${ }^{1}$
}

Author for correspondence: Grzegorz Węgrzyn. Tel: +4858346 3014. Fax: +48583010072. e-mail: wegrzyn@biotech.univ.gda.pl

1 Laboratory of Molecular Genetics, Department of Molecular Biology, University of Gdansk, Kładki 24, 80-822 Gdańsk, Poland

2 Institute of Biochemistry and Biophysics, Polish Academy of Sciences, Laboratory of Molecular Biology affiliated to the University of Gdansk, Kładki 24, 80-822 Gdańsk Poland

3 Division of Molecular and Genetic Medicine, University of Sheffield Medical School, Beech Hill Road, Sheffield S10 2RX, UK

\begin{abstract}
Bacteriophage $\lambda$ is unable to lysogenize Escherichia coli hosts harbouring the rpoA341 mutation due to a drastic reduction in transcription from Cll-activated lysogenic promoters $\left(p_{E}, p_{1}\right.$ and $\left.p_{\mathrm{aq}}\right)$. In addition, the level of early transcripts involved in the lytic pathway of $\lambda$ development is also decreased in this genetic background due to impaired $\mathbf{N}$-dependent antitermination. Here, it is demonstrated that despite the reduced level of early lytic $p_{L}$ - and $p_{R}$-derived transcripts, lytic growth of bacteriophage $\lambda$ is not affected in rich media. The level of the late lytic, $p_{\mathrm{R}}$-derived transcripts also remains unaffected by the rpoA341 mutation under these conditions. However, it was found that whilst there is no significant difference in the phage burst size in rpoA $A^{+}$and rpoA341 hosts growing in rich media, phage $\lambda$ is not able to produce progeny in the rpoA341 mutant growing in minimal medium, in contrast to otherwise isogenic rpoA ${ }^{+}$bacteria. Provision of an excess of the phage replication proteins $\mathbf{O}$ and $\mathbf{P}$ in trans or overproduction of the antitermination protein $\mathbf{N}$ restore the ability of phage $\lambda$ to produce progeny in the rpoA341 mutant under the latter conditions. These results suggest that in rich media phage $\lambda$ produces some early proteins in excess of that needed for its effective propagation and indicate that replication proteins may be limiting factors for phage lytic growth in poor media.
\end{abstract}

Keywords: bacteriophage $\lambda$ development, Escherichia coli rpoA341 mutation, phage $\lambda$ gene expression, $\lambda$ replication proteins, bacterial growth rate

\section{INTRODUCTION}

As a temperate phage, $\lambda$ is able to enter either of two alternative modes of development upon infection of Escherichia coli: the lytic and lysogenic pathways (for reviews see Echols, 1986; Ptashne, 1992). However, the physiological conditions under which the lytic pathway is entered may vary considerably. For example, although lysogenic development is preferred in bacteria infected by many phages simultaneously and growing in poor media, there is only a small possibility that lysogenization will occur when the host cell is infected by a single phage irrespective of the growth conditions (for reviews see Herskowitz \& Hagen, 1980; Herskowitz, 1985; Taylor \& Węgrzyn, 1998). Therefore, $\lambda$ must be able to maximize its yield of progeny under these different conditions. Although bacteriophages have played a crucial role in the development of molecular biology, most experiments on phage genetics and biochemistry have been performed under laboratory conditions supporting near maximum growth rates of the host bacterium, a situation which may be far removed from that found in the natural environment of $E$. coli. Therefore, the full extent to which growth conditions and the physiological state of the host cell influences phage development, as well as phage strategies which could ensure its effective propagation under different environmental conditions, may have been overlooked (see Hadas et al., 1997).

We demonstrated previously that a mutation, rpoA341, in the gene encoding the $\alpha$ subunit of E. coli RNA polymerase prevents lysogenization by bacteriophage $\lambda$ (Wegrzyn et al., 1992a). We proposed, and recently confirmed experimentally, that impaired lysogenization of rpoA341 hosts results from drastically decreased transcription from the CII-activated promoters $p_{\mathrm{E}}, p_{\mathrm{I}}$ and $p_{\mathrm{aQ}}$, which are necessary for establishment of a $\lambda$ 
prophage (Weggrzyn et al., 1992a; Szalewska-Pałasz et al., 1996; Obuchowski et al., 1997b). In addition, we found that the level of the longer transcripts derived from the early lytic $p_{\mathrm{L}}$ and $p_{\mathrm{R}}$ promoters was also decreased in the phage-infected rpoA341 mutant due to impaired antitermination at the $t_{\mathrm{L} 1}$ and $t_{\mathrm{R} 1}$ terminators (Szalewska-Palasz et al., 1996; Obuchowski et al., 1997a) (a genetic map of bacteriophage $\lambda$ is shown in Fig. 1 ). Thus, it would seem likely that lytic growth of bacteriophage $\lambda$ should also be compromised in the rpoA341 mutant. The aim of this work was to examine the effect of the rpoA341 mutation on $\lambda$ lytic growth. Contrary to expectation, our results show that there are no phenotypic differences between $\lambda$ lytic development in $r p o A^{+}$and $r p o A 341$ hosts growing in rich media, whereas an effect is observed under conditions supporting slow growth of the host. These observations can be rationalized as part of an overall strategy for the effective propagation of the phage in the host cell under a range of nutritional conditions.

\section{METHODS}

Bacterial strains, phages and plasmids. Otherwise isogenic $\left[\mathrm{F}^{-}\right.$araD139 $\Delta($ argF-lac $)$ U169 $\Delta($ bis-gnd $)$ thi rpsL150 glts flbB5301 relA1 deoC1 rbsR] rpoA341 and rpo $A^{+}$strains of $E$. coli K-12 (WAM105 and WAM106, respectively) have been described previously (Thomas \& Glass, 1991). Bacteriophages $\lambda c 1857 S 7$ (Goldberg \& Howe, 1969), $\lambda c 17, \lambda c 1857 c 1168$ (Obuchowski et al., 1997c), גc17cll68 (from A. B. Oppenheim, The Hebrew University Hadassah Medical School, Jerusalem, Israel) and $\lambda c l b 2$ (from our collection) were used. For providing $\mathrm{O}$ and $\mathrm{P}$ proteins in trans we used plasmid pTC $\lambda 1$ (Herman-Antosiewicz et al., 1998), which contains the phage $\lambda O$ and $P$ genes under control of the tet $A$ gene promoter. This promoter is repressed by the $\mathrm{pTC} \lambda 1$-encoded TetR repressor, and transcription of the $O$ and $P$ genes can be induced by autoclaved chlortetracycline (which does not act as an antibiotic but is still active as an inducer). Overproduction of the phage antiterminator protein, $\mathrm{N}$, was achieved using plasmid pSS125 (Sullivan \& Gottesman, 1992; Obuchowski et al., 1997a) harbouring the $N$ gene under control of the $p_{\text {lac }}$ promoter and the $\operatorname{lacl}^{\mathrm{Q}}$ allele (IPTG was used as an inducer). Plasmid pGAW 9035 was constructed by ligation of a 9035 bp $\lambda$ DNA fragment, stretching from the EcoRI site at 44972 through $\cos$ to the BamHI site at 5505 , with the $3315 \mathrm{bp}$ EcoRI-BamHI fragment of pBR328 (Soberon et al., 1980).

Culture media. The following media were used: Luria-Bertani (LB) broth (Sambrook et al., 1989); MMGluCaa (termed minimal medium 1 by Weqgrzyn et al., 1991), composed of salts (for details see Wegrzyn et al., 1991), thiamin $\left(10 \mu \mathrm{g} \mathrm{ml}^{-1}\right)$, Casamino acids $(1 \%, w / v)$ and glucose $(1 \%, w / v)$; and MMGlu, in which the Casamino acids of MMGluCaa are replaced with $\mathrm{L}$-histidine and $\mathrm{L}$-cysteine (each at a final concentration of $100 \mu \mathrm{g} \mathrm{ml}^{-1}$ ).

DNA techniques. All DNA manipulations (molecular cloning and preparation of DNA templates for construction of labelled probes) were carried out according to Sambrook et al. (1989).

Kinetics of bacteriophage $\lambda$ lytic growth and burst size determination. Lytic development of bacteriophage $\lambda$ was investigated by one-step growth experiments as described previously (Szalewska et al., 1994). Briefly, bacteria growing exponentially in the appropriate medium were infected by $\lambda$ phage in the presence of $3 \mathrm{mM} \mathrm{NaN}$ (to prevent unsynchronized phage development) at the indicated m.o.i. and adsorption was carried out for $10 \mathrm{~min}$. Following centrifugation, the bacterial pellet was resuspended in the same medium (with $\mathrm{NaN}_{3}$ ) containing anti- $\lambda$ serum and incubated for $5 \mathrm{~min}$ to neutralize unadsorbed phages. The suspension was then diluted 1000 -fold with the prewarmed medium (devoid of $\mathrm{NaN}_{3}$ ) and aerated in a water-bath shaker. The number of 'infective centres' was estimated by plating of samples taken during the first $10 \mathrm{~min}$ after dilution (time $0-10 \mathrm{~min})$. The estimated number of 'infective centres' is in fact the sum of the number of infected bacteria and the number of free, unadsorbed phages. However, as most of the unadsorbed phage particles were neutralized by anti- $\lambda$ serum the second value was ignored during the calculation of the burst size. The number of intracellular progeny phages was estimated by plating of chloroform-treated samples of the infected culture withdrawn at different times. The burst size was calculated as the ratio of the number of progeny phages to the number of infective centres. In Table 1 , the burst size is provided as the only measurement of $\lambda$ lytic growth and was calculated from samples taken at times when the phage growth curve reached a plateau.

Estimation of the rate of bacteriophage $\lambda O$ protein synthesis. Bacteria growing at $30^{\circ} \mathrm{C}$ in $\mathrm{LB}$ or MMGlu medium were infected with phage $\lambda c I 857 S 7$ at an m.o.i. of 10 and samples were taken for pulse labelling $5 \mathrm{~min}$ post-infection as $\mathrm{O}$ protein synthesis is maximal at this stage (Wegrzyn et al., 1992b). Measurement of the synthesis of bacteriophage $\lambda-O$ protein was performed by pulse labelling $(5 \mathrm{~min})$ with $\left.{ }^{35} \mathrm{~S}\right]$ methionine and immunoprecipitation of cell lysates with anti- $\lambda$ O serum followed by SDS-PAGE and autoradiography as described previously (Węgrzyn et al., 1992b). Because LB medium contains a relatively high concentration of peptides and amino acids, a 10-fold higher amount of radiolabelled methionine was used in experiments performed in this medium relative to experiments performed in MMGlu medium. Moreover, during autoradiography, the films from different experiments were exposed for various times to achieve the best resolution. Therefore, the results presented in Fig. 2 may be directly compared within one panel but not between panels.

Analysis of phage protein synthesis in $\lambda$-infected cells. Phage protein synthesis in $\lambda$-infected cells was measured in pulselabelling experiments as described previously (Gottesman et $a l ., 1981)$. The bands on the autoradiogram, identified on the basis of their migration in the gel relative to molecular mass standards, were quantified by densitometry using a UVP Enhanced Analysis System (EASY).

Measurement of the level of phage transcripts. The level of longer, antiterminated (due to $Q$ protein activity), late transcripts derived from the bacteriophage $\lambda p_{R^{\prime}}$ promoter was estimated on the basis of Northern hybridization. Northern blot experiments were performed as described previously (Wegrzyn, A. et al., 1995). Bacteria were infected with phage $\lambda c I 857 S 7$ at an m.o.i. of 10 and samples were withdrawn $35 \mathrm{~min}$ post-infection, as the amount of late transcripts reaches a maximum around this time (Echols, 1971). The template for labelling of the probe designed for detection of $p_{\mathbf{R}^{\prime}}$-derived transcripts was the EcoRI-BamHI $\lambda$ DNA insert of plasmid pGAW9035.

Analysis of $\lambda \mathbf{E}$ protein abundance. Detection of the $\lambda \mathbf{E}$ protein in phage-infected cells was performed by Western blotting as described previously (Węgrzyn, A. et al., 1995). Anti- $\lambda \mathrm{E}$ serum was provided by A. Taylor, S. Kędzierska and E. Laskowska (University of Gdańsk, Poland). 


\section{RESULTS}

\section{Lytic development of bacteriophage $\lambda$ in the $E$. coli rpoA341 host}

We examined whether impaired $\mathrm{N}$-dependent antitermination at $t_{\mathrm{L} 1}$ and $t_{\mathrm{R} 1}$ compromises lytic growth of phage $\lambda$ in an rpoA341 background. Surprisingly, estimation of the efficiency of plating (Szalewska-Palasz et al., 1996), burst size measurements with $\lambda c I b 2$ (Table 1) and kinetics of production of phage progeny (measured in one-step growth experiments, data not shown) revealed no significant differences between $\lambda$ lytic development in $r p o A^{+}$and $r p o A 341$ strains growing in LB. To eliminate the possibility that these results were due to differences in the phage strains used or conditions employed for measuring transcript abundance on the

Table 1. Effects of the host rpoA341 mutation, phage $c 17$ mutation and overproduction of phage $\mathrm{O}, \mathrm{P}$ and $\mathrm{N}$ proteins on mean phage burst size

Otherwise isogenic rpoA341 (WAM105) and $r p o A^{+}$(WAM106) strains were used as hosts.

Infections were performed at an m.o.i. of 0.05 in different media at $30^{\circ} \mathrm{C}$. Mean burst size (in p.f.u. per infective centre) was calculated on the basis of one-step growth experiments performed as described in Methods. The data presented are based on at least three measurements.

\begin{tabular}{|c|c|c|c|c|c|c|c|}
\hline \multirow{2}{*}{$\begin{array}{l}\text { Growth } \\
\text { medium* }\end{array}$} & \multirow{2}{*}{$\begin{array}{l}\text { Plasmid } \\
\text { in host } \dagger\end{array}$} & \multicolumn{2}{|c|}{$\lambda c I b 2$} & \multicolumn{2}{|c|}{$\lambda c 17$} & \multicolumn{2}{|c|}{$\lambda c 17 c 1168$} \\
\hline & & rро $A 341$ & $\boldsymbol{r p o} A^{+}$ & rpoA341 & $\boldsymbol{r p o} A^{+}$ & $\operatorname{rpo} A 341$ & $\operatorname{rpo} A^{+}$ \\
\hline LB & None & 109 & 115 & 111 & 96 & 94 & 146 \\
\hline MMGluCaa & None & 27 & 32 & 29 & 44 & 31 & 35 \\
\hline MMGlu & None & $<0.01$ & 4 & 21 & 32 & 16 & 17 \\
\hline MMGlu & pTC $\lambda 1$ & 23 & 35 & NT & NT & NT & NT \\
\hline MMGlu & pSS125 & 15 & 85 & NT & NT & NT & NT \\
\hline
\end{tabular}

NT, Not tested.

* Media compositions are described in Methods. Bacterial growth rates in different media were: for the rpoA341 (WAM105) strain, $1.90,1.55$ and 1.10 doublings $\mathrm{h}^{-1}$ in LB, MMGluCaa and MMGlu, respectively; for the rpo $A^{+}$(WAM106) strain, 2.00, 1.60 and 1.15 doublings $\mathrm{h}^{-1}$ in LB, MMGluCaa and MMGlu, respectively.

† Overexpression of the $O$ and $P$ genes from plasmid pTC $\lambda 1$ was achieved by addition of autoclaved chlortetracycline to the medium to a final concentration of $10 \mu \mathrm{g} \mathrm{ml}^{-1}$. Overexpression of the $N$ gene from plasmid pSS125 was achieved by addition of IPTG to the medium to a final concentration of $1 \mathrm{mM}$. Both inducers were present in the medium overnight and throughout the whole experiment.

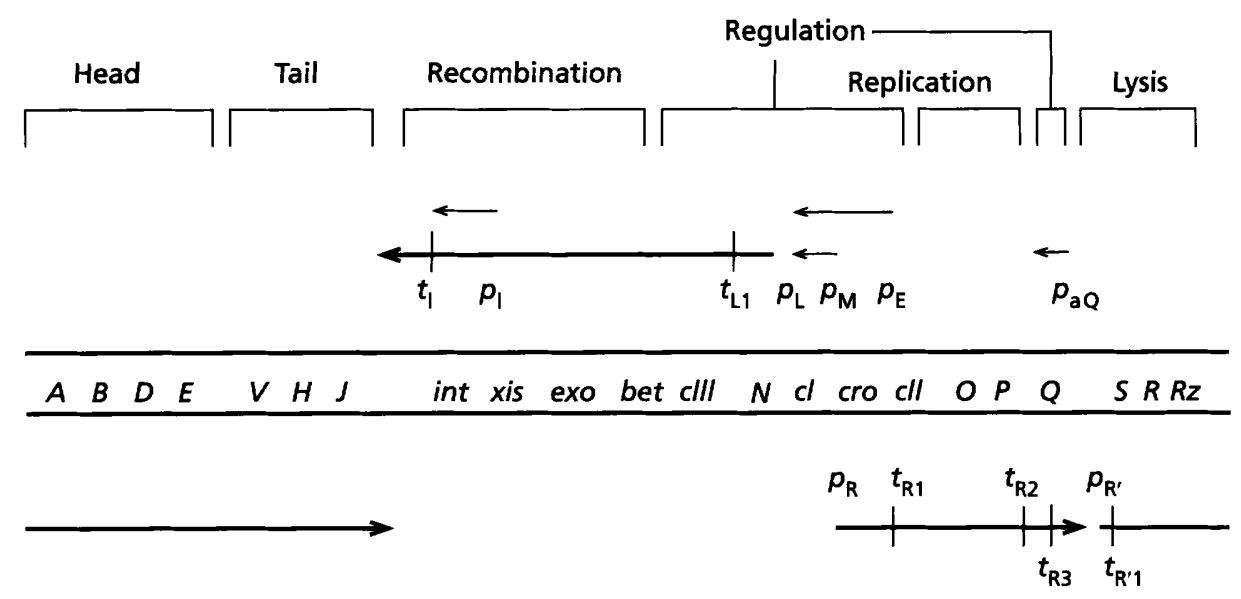

Fig. 1. Map of the bacteriophage $\lambda$ genome. The most important genes and their roles in phage development are indicated. Transcripts specifying lytic functions are marked as thick arrows; transcripts necessary for the establishment of the lysogenic pathway of $\lambda$ development and maintenance of the prophage are marked as narrow arrows. The main promoters $(p)$ and terminators $(t)$ are also shown. $\mathrm{N}$-dependent antitermination occurs at $t_{\mathrm{L} 1}$ as well as at $t_{\mathrm{R} 1}$ and more distal terminators. Q-dependent antitermination occurs at the $t_{R^{\prime},}$ terminator. The scheme is not drawn to scale. 
(a)

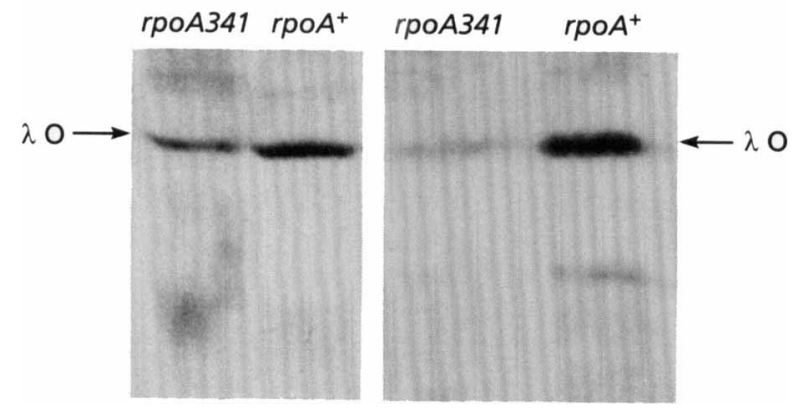

Fig. 2. Synthesis of the phage $O$ protein in $\lambda \mathrm{c} / 85757$-infected rpoA341 (WAM105) and rpoA ${ }^{+}$(WAM106) hosts growing in LB medium (a) and MMGlu (b) between 5 and $10 \mathrm{~min}$ postinfection at $30^{\circ} \mathrm{C}$. Note that due to different amounts of $\left[{ }^{35} \mathrm{~S}\right]$ methionine used in the different media and the different times of film exposure during autoradiography, the results presented in this figure (particularly band intensities) should not be directly compared between panels (see Methods for details).

one hand (Szalewska-Pałasz et al., 1996; Obuchowski et al., 1997a) and lytic growth on the other, we repeated measurements of the burst size of $\lambda c 1857 S 7$ and $\lambda c I b 2$ phages at different temperatures and m.o.i. values. However, under these alternative conditions we were again unable to detect any significant differences in the lytic development of bacteriophage $\lambda$ in the two host strains (data not shown).

\section{Synthesis of bacteriophage $\lambda O$ protein in the $E$. coli rpoA341 host}

The results presented above suggest that decreased synthesis of certain delayed early proteins can still support normal lytic growth of the phage in rich media. To test this idea we examined the synthesis of $O$ protein, the initiator of $\lambda$ DNA replication, which is encoded by the $\mathrm{N}$-antiterminated, $p_{\mathrm{R}}$-derived, delayed early lytic transcript (Fig. 1). As expected, we observed a marked reduction in the level of O protein synthesis in $\lambda$ cI857S7infected $r p o A 341$ bacteria relative to the $r p o A^{+}$host (Fig. 2a). These results indicate that in a bacterial host growing in rich media bacteriophage $\lambda$ produces $\mathrm{O}$ protein (and probably other delayed early proteins) in excess of that required to achieve normal lytic growth. One implication of this observation is that effective growth of the phage may be achieved even under conditions which are far from optimal for lytic growth, i.e. conditions which might result in decreased $O$ synthesis or activity. In control experiments we found no significant differences in the synthesis of the immediate early gene product, Cro (the gene for which is located upstream of the $t_{\mathrm{R} 1}$ terminator), in UVirradiated $\lambda c 1857 S 7$-infected $r p o A^{+}$and $r p o A 341$ hosts (data not shown). In the same experiments, decreased synthesis of the replication proteins $\mathrm{O}$ and $\mathrm{P}$ was again observed in the rpoA341 mutant relative to the $r p o A^{+}$ strain (data not shown).
Bacteriophage $\lambda$ lytic development under different growth conditions

One prediction from our observations is that under certain conditions delayed early lytic proteins will become limiting for $\lambda$ growth in the rpoA341 host but not in the wild-type host. Therefore, we investigated $\lambda$ lytic development in $r p o A^{+}$and $r p o A 341$ hosts under different nutritional conditions. We found that although there was no significant difference between $\lambda c l b 2$ lytic development in $r p o A^{+}$and $r p o A 341$ hosts growing in relatively rich media ( $\mathrm{LB}$ or MMGluCaa), the phage could not produce its progeny efficiently in the mutant host in poor medium (MMGlu), in contrast to the situation in the $r p o A^{+}$strain in which the yield of progeny was decreased relative to that in rich media but was still significant (Table 1). This observation cannot be attributed to differences in growth rates between the two hosts as both have similar doubling times (Table 1).

\section{Overexpression of phage replication proteins can restore efficient $\lambda$ lytic development in the rpoA341 host growing in minimal medium}

We found that, similarly to the situation observed in a rich medium (Fig. 2a), synthesis of $O$ protein was significantly decreased in the $r p o A 341$ host relative to the $r p o A^{+}$strain growing in a poor medium (MMGlu, Fig. 2b). Therefore, we investigated whether this protein was a limiting factor for $\lambda$ lytic development under these growth conditions. We found that artificially raising the level of the phage replication proteins $(\mathrm{O}$ and $\mathrm{P})$ in trans resulted in an increase in the yield of phage $\lambda c I b 2$ progeny in the $r p o A^{+}$host growing in minimal medium to a level similar to that obtained in MMGluCaa in the absence of overproduced $\mathrm{O}$ and $\mathrm{P}$ (Table 1). Even more striking was the restoration of the ability of $\lambda$ to develop lytically in the rpoA341 mutant under these growth conditions, again to a level similar to that observed in MMGluCaa (Table 1). In analogous experiments, when $\mathrm{O}$ and $\mathrm{P}$ were oversupplied in $r p o A^{+}$and $r p o A 341$ bacteria growing in LB or MMGluCaa medium, we did not observe any increase in the phage burst size (data not shown). These results indicate that the activity of the replication proteins is likely to be a limiting factor for phage lytic growth under conditions unfavourable for growth of the host, but not under favourable conditions.

The $\mathrm{O}$ and $\mathrm{P}$ proteins are encoded by genes which are transcribed from the $p_{R}$ promoter but are located downstream of the weak $t_{\mathrm{R} 1}$ terminator (Fig. 1). Thus, for maximal expression the $O$ and $P$ genes require $N$ dependent transcriptional antitermination at $t_{\mathrm{R} 1}$ (for a review see Friedman \& Court, 1995). It was demonstrated that $\mathrm{N}$-mediated antitermination is less efficient in the rpoA341 mutant and that this defect can be compensated for by overproduction of $\mathrm{N}$ protein (Obuchowski et al., 1997a). Accordingly, we found that overexpression of the $N$ gene from plasmid pSS125 results in improved phage lytic development in both $r p o A^{+}$and rpoA341 hosts growing in MMGlu, though the yield of phage progeny was higher in the $r p o A^{+}$ 


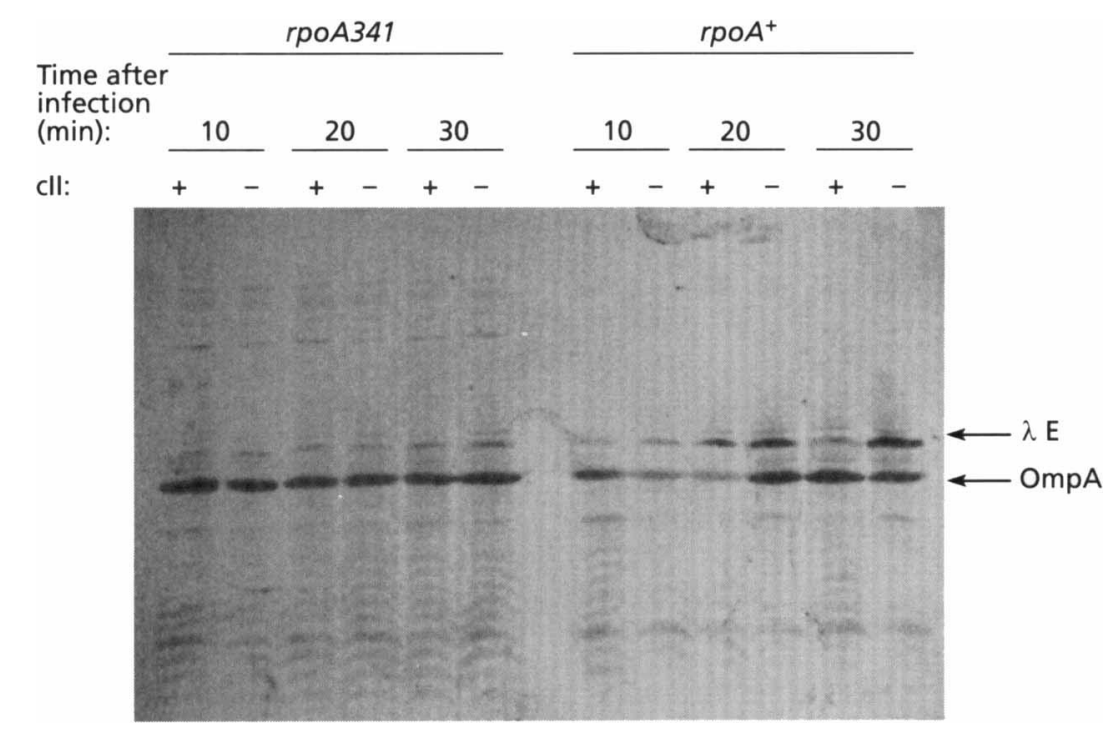

\begin{abstract}
Fig. 3. Western blotting analysis of the abundance of the $\lambda \mathrm{E}$ protein in rpoA341 (WAM105) and rpoA $^{+}$(WAM106) hosts following infection by $\lambda \mathrm{clb2}\left(\lambda \mathrm{Cl} \mathrm{I}^{+}\right)$and $\lambda \mathrm{cl} 857 \mathrm{cll} 68(\lambda \mathrm{cl})$ phages at $30^{\circ} \mathrm{C}$. Samples were withdrawn 10, 20 and $30 \mathrm{~min}$ postinfection, cells were lysed and following $12.5 \%$ SDS-PAGE of lysates and transfer to a nitrocellulose membrane, the $\lambda E$ protein was detected by Western blotting using anti- $\lambda E$ serum. The OmpA protein was detected on the same blot and served as an internal control.
\end{abstract}

strain (Table 1), presumably because $\mathrm{N}$ synthesis from pSS125 is not sufficient to restore maximum antitermination efficiency in the mutant host (Obuchowski et al., 1997a). In the rpo $A^{+}$host we observed a burst size almost as high as in hosts growing in LB medium (Table 1). This more substantial effect of $\mathrm{N}$ overproduction than provision of $\mathrm{O}$ and $\mathrm{P}$ functions may result from the fact that $\mathrm{O}$ complementation is known to be relatively poor in trans (Wyatt \& Inokuchi, 1974) due to instability of uncomplexed O protein in E. coli cells (Lipińska et al., 1980; Gottesman et al., 1981; Węgrzyn et al., 1992b), or it may be due to the provision of increased levels of other $\mathrm{N}$-dependent delayed early lytic proteins which would otherwise be limiting under these conditions.

We also investigated lytic development of $\lambda$ carrying the c17 mutation, which allows for effective expression of the $O$ and $P$ genes in the absence of $\mathrm{N}$-dependent antitermination due to the creation of another rightward promoter (Packman \& Sly, 1968; Rosenberg et al., 1978). The $\lambda c 17$ cll68 mutant was also used to eliminate any possible effects of the cII gene product which is inactive in the rpoA341 host. As expected, we observed growth-rate-regulated development of the phages in both the $r p o A^{+}$and $r p o A 341$ strains, but no significant differences were detected between the burst sizes in these two hosts under any of the growth conditions tested (Table 1). These results further support our contention that delayed early proteins become limiting for growth of phage $\lambda$ in MMGlu and that the effect is more marked in the rpoA341 host due to the impairment of $\mathrm{N}$-dependent antitermination.

\section{Bacteriophage $\lambda$ late transcription and expression of the late gene, $E$, in the $E$. coli rpoA341 host}

Phage burst size is also dependent on the level of capsid protein synthesis. The head and tail genes are transcribed from the late promoter $p_{R^{\prime}}$, but they also require the action of a delayed early lytic protein, the $Q$ antiterminator, for their expression (Fig. 1). The expression of the $Q$ gene, like $O$ and $P$, is dependent on $\mathrm{N}$ stimulated transcriptional readthrough of $t_{\mathrm{R} 1}$ and downstream terminators (Fig. 1) and would therefore be expected to be depressed in the $\lambda$-infected $r p o A 341$ mutant. Any such decrease in $Q$ synthesis may be manifested in an observed reduction in the level of $p_{\mathrm{R}^{\prime}}$ derived transcripts. However, we found that the level of $p_{\mathbf{R}^{\prime}}$-derived late transcripts is almost identical in $r p o A^{+}$ and $r p o A 341$ strains following infection with $\lambda$ cl857S7 (data not shown). As late gene expression in phage $\lambda$ is down-regulated through the action of CII protein at the $p_{\mathrm{aQ}}$ promoter we speculated that the absence of anti- $Q$ RNA synthesis in the rpoA341 host compensates for this decreased readthrough transcription into $Q$. To test this idea we measured the abundance of one of the $\lambda$ late proteins, $\mathrm{E}$, in $r p o A^{+}$and $r p o A 341$ bacteria infected by $\lambda \mathrm{CII}^{+}$and $\lambda \mathrm{cll}$ phages. As expected, we found that expression of the $E$ gene is enhanced in the $r p o A^{+}$host infected by the $\lambda c I I$ mutant relative to $\lambda c I^{+}$phage infection (Fig. 3). However, no such effect was observed in the rpoA341 host as this strain causes a phenotypic $\mathrm{CII}^{-}$condition (Fig. 3).

\section{DISCUSSION}

Although levels of bacteriophage $\lambda$ transcripts derived from the $p_{\mathrm{R}}$ and $p_{\mathrm{L}}$ promoters are decreased in the $E$. coli rpoA341 mutant relative to the $r p o A^{+}$host due to impaired $\mathrm{N}$-dependent transcriptional antitermination (Szalewska-Pałasz et al., 1996; Obuchowski et al., 1997a), we did not observe any significant differences in phage lytic development between both strains growing in LB medium, i.e. under standard laboratory conditions. This is despite the fact that the phage replication proteins $\mathrm{O}$ and $\mathrm{P}$ are produced less efficiently in the rpoA341 mutant under these conditions. The most straightforward hypothesis to explain the absence of any obvious impairment of phage lytic development in the presence of depressed delayed early gene expression 
is that phage $\lambda$ produces an excess of certain proteins in rich media. One might expect that synthesis of all phage components should be optimally co-regulated during the infection cycle and that the amount of each component should not exceed that necessary for maximum growth under any given set of conditions. Since this does not appear to be the case, there must be a reason why evolution preferred overproduction of some phage proteins. We propose that under favourable growth conditions (for example, in LB medium with good aeration, etc., i.e. under standard laboratory conditions) phage $\lambda$ produces at least some proteins in excess of that needed for its effective propagation. Thus, efficient lytic growth of the phage may be achieved even under less favourable conditions. Accordingly, we found that whereas a mutant host which retards expression of early lytic genes is able to support normal lytic growth of phage $\lambda$ in rich media, it fails to support phage growth in nutritionally poor medium. Thus, we propose that whilst the level of certain phage proteins such as $\mathrm{O}$ and $\mathrm{P}$ decreases as the nutritional quality of the growth media decreases to the point where they become limiting for phage growth in wild-type bacteria, the level of these proteins in the rpoA341 mutant is lower still, such that effective phage lytic development becomes impossible.

The inhibition of lytic growth in the $\mathrm{N}$-antiterminationdefective $r p o A 341$ mutant growing in MMGlu suggests that the activity of one or more products of the delayed early lytic transcripts is limiting under these conditions. Looking for potential candidates for the limiting factors in $\lambda$ lytic development under unfavourable conditions, we found that overproduction of the replication proteins $\mathrm{O}$ and $\mathrm{P}$, as well as overexpression of the $N$ gene (encoding an antitermination protein), can restore the ability of $\lambda$ to produce progeny in the rpoA341 host growing in minimal medium. Therefore, the replication proteins may be the limiting factors or, alternatively, limited expression of $N$ might result in decreased levels of $O$ and $P$ due to inefficient transcriptional antitermination at $t_{\mathrm{R} 1}$. However, overproduction of $\mathrm{O}$ and $\mathrm{P}$ in MMGluCaa and LB has no effect on lytic growth of the phage. Furthermore, whilst lytic growth of the phage is downregulated in cells growing in MMGluCaa relative to cells growing in $\mathrm{LB}$, the burst size in the mutant host remains the same as in the wild-type. Since the synthesis of $O$ protein in the mutant host growing in MMGluCaa is depressed relative to the wild-type, the level of $\mathrm{O}$ cannot be limiting for phage growth under these conditions. By implication, the observed fall in the burst size in this medium probably results from decreased activity of some other phage protein(s) (though not delayed early proteins) or, more likely, the involvement of host factor(s). Why does the activity of $\mathrm{O}$ and/or $\mathrm{P}$ become limiting under conditions allowing slow growth of the host? One possible reason for this is that the activity of the $p_{\mathrm{R}}$ and/or $p_{\mathrm{L}}$ promoter(s) may be growth-rate-regulated. However, using $p_{\mathrm{R}}-$ lac $Z$ and $p_{\mathrm{L}}-$ lac $Z$ fusions, we were not able to detect an obvious positive correlation between the bacterial growth rate and the activities of these promoters (data not shown).
The possibility remains that the level of at least some phage components is depressed in poor media as a consequence of a decrease in the translational capacity of the cell at slow growth rates. Such a model has been recently proposed as an explanation of decreased efficiency of bacteriophage T4 development in E. coli cells growing in poor media (Hadas et al., 1997).

Our proposal that under favourable growth conditions phage $\lambda$ produces an excess of certain proteins is supported by some recently published studies on $\lambda \mathrm{O}$ protein. As mentioned above, the $\mathrm{O}$ protein is very unstable in the free form (Lipińska et al., 1980; Gottesman et al., 1981) but is stabilized in the replication complex (Węgrzyn et al., 1992b; Pawlowicz et al., 1993; Węgrzyn, A. et al., 1995), a structure which is inherited by one of two daughter DNA copies after a replication round and may function in the next replication event (Kur et al., 1987; Węgrzyn \& Taylor, 1992; SzalewskaPałasz \& Węgrzyn, 1994; Szalewska-Pałasz et al., 1994; Taylor \& Węgrzyn, 1995; Węgrzyn, 1995; Węgrzyn \& Węgrzyn, 1995; Węgrzyn, A. et al., 1996). It was demonstrated that overproduction of ClpXP protease, which specifically degrades the $O$ protein, does not affect the replication of phage $\lambda$ and plasmids derived from this phage in rich media (Szalewska et al., 1994). This observation can be reconciled with our hypothesis that $O$ protein is produced in excess under these conditions such that the level of the unproteolysed form of this protein is still sufficient to maintain efficient $\lambda$ phage and plasmid replication. Moreover, clpP and $c l p X$ null mutations had no significant effect on phage $\lambda$ burst size or $\lambda$ plasmid copy number in bacteria growing in rich media (Szalewska et al., 1994), again indicating that $\mathrm{O}$ protein is probably produced in excess under these growth conditions.

Further support for our proposed hypothesis comes from studies on the role of the host $d n a A$ gene function in replication of bacteriophage $\lambda$. It was demonstrated that DnaA positively regulates the activity of the phage promoter $p_{\mathrm{R}}$ (Węgrzyn, G. et al., 1995a, 1996; Szalewska-Pałasz et al., 1998). These studies also indicated that both the level of $p_{R}$-derived transcripts and the synthesis of $O$ protein are significantly decreased in a temperature-sensitive $d n a A 46$ mutant at $43^{\circ} \mathrm{C}$. Nevertheless, lytic development of phage $\lambda$ in this host was found to be apparently normal at the non-permissive temperature in rich medium (Wegrzyn, G. et al., 1995b). The experimental system described above is analogous to that described in this paper, i.e. a host mutant (dnaA46 or rpoA341) that causes a decrease in the level of $\lambda$ replication proteins is nevertheless able to support normal lytic growth of the phage in rich media. Staying with this analogy, we have subsequently found that phage $\lambda$ lytic development is impaired in the dnaA46 mutant growing in minimal medium at $43{ }^{\circ} \mathrm{C}$ (data not shown).

We have also demonstrated that in the $\lambda$-infected rpoA341 mutant the level of the longer $\mathrm{Q}$-antiterminated $p_{\mathrm{R}^{\prime}}$-derived transcripts is not depressed relative to the 
$r p o A^{+}$strain. This might seem unexpected in view of the fact that late gene expression requires the action of the $\mathrm{Q}$ antiterminator, the synthesis of which is dependent on $\mathrm{N}$-mediated transcriptional antitermination at $t_{\mathrm{R} 1}$ and more distant terminators (Fig. 1). Since this process is impaired in the rpoA341 mutant (Obuchowski et al., 1997a), one might consequently expect a lower level of the $\mathrm{Q}$ protein and a correspondingly decreased level of longer $p_{\mathrm{R}^{\prime}}$-derived transcripts. However, in addition to the positive effect of $\mathrm{N}$ protein on $Q$ gene expression, $\mathrm{Q}$ protein synthesis is negatively regulated by antisense RNA appearing as a result of the activity of the CIIdependent $p_{\mathrm{aQ}}$ promoter (Ho \& Rosenberg, 1985; Hoopes \& McClure, 1985). Since we have demonstrated that the level of $p_{\mathrm{a} Q}$-initiated transcripts is drastically decreased in the $\lambda$-infected $r$ poA341 mutant (SzalewskaPalasz et al., 1996), the simplest explanation of our results is that the absence of negative regulation of $Q$ gene translation by $p_{\mathrm{aQ}}$-derived antisense RNA compensates for the decrease in $\mathrm{N}$-dependent transcription of $Q$. In short, although the level of $Q$ transcripts is depressed in the rpoA341 host, they may be translated more efficiently.

\section{ACKNOWLEDGEMENTS}

We thank A. B. Oppenheim for providing phage mutants and A. Taylor, S. Kędzierska and E. Laskowska for providing anti- $\lambda$ E serum. M.O. is a recipient of the fellowship from the Foundation for Polish Science in 1997. This work was supported by the Polish State Committee for Scientific Research (KBN, project number 6 P04A 059 09).

\section{REFERENCES}

Echols, H. (1971). Regulation of lytic development. In The Bacteriophage Lambda, pp. 247-270. Edited by A. D. Hershey. Cold Spring Harbor, NY: Cold Spring Harbor Laboratory.

Echols, H. (1986). Bacteriophage $\lambda$ development: temporal switches and the choice of lysis or lysogeny. Trends Genet 2, 26-30.

Friedman, D. I. \& Court, D. L. (1995). Transcription antitermination : the $\lambda$ paradigm updated. Mol Microbiol 18, 191-200.

Goldberg, A. R. \& Howe, M. (1969). New mutations in the $S$ cistron of bacteriophage lambda affecting host cell lysis. Virology 38, 200-202.

Gottesman, S., Gottesman, M., Shaw, J. E. \& Pearson, M. L. (1981). Protein degradation in E. coli: the lon mutation and bacteriophage lambda $\mathrm{N}$ and cll protein stability. Cell 24, 225-233.

Hadas, H., Einav, M., Fishov, I. \& Zaritsky, A. (1997). Bacteriophage T4 development depends on the physiology of its host Escherichia coli. Microbiology 143, 179-185.

Herman-Antosiewicz, A., Śrutkowska, S., Taylor, K. \& Węgrzyn, G. (1998). Replication and maintenance of $\lambda$ plasmids devoid of the Cro repressor autoregulatory loop in Escherichia coli. Plasmid (in press).

Herskowitz, I. (1985). Master regulatory loci in yeast and lambda. Cold Spring Harbor Symp Quant Biol 50, 565-574.

Herskowitz, I. \& Hagen, D. (1980). The lysis-lysogeny decision of phage $\lambda$ : explicit programming and responsiveness. Annu Rev Genet 14, 399-445.
Ho, Y. S. \& Rosenberg, M. (1985). Characterization of a third, CIIdependent, coordinately activated promoter on phage $\lambda$ involved in lysogenic development. J Biol Chem 260, 11838-11844.

Hoopes, B. C. \& McClure, W. (1985). A cII-dependent promoter is located within the Q-gene of bacteriophage $\lambda$. Proc Natl Acad Sci USA 82, 3134-3138.

Kur, J., Górska, I. \& Taylor, K. (1987). Escherichia coli dnaA initiation function is required for replication of plasmids derived from coliphage lambda. J Mol Biol 198, 203-210.

Lipińska, B., Podhajska, A. \& Taylor, K. (1980). Synthesis and decay of $\lambda$ DNA replication proteins in minicells. Biochem Biophys Res Commun 92, 120-126.

Obuchowski, M., Wegrzyn, A., Szalewska-Pałasz, A., Thomas, M. S. \& Węgrzyn, G. (1997a). An RNA polymerase $\alpha$ subunit mutant impairs $\mathrm{N}$-dependent transcriptional antitermination in Escherichia coli. Mol Microbiol 23, 211-222.

Obuchowski, M., Giladi, H., Koby, S., Szalewska-Pałasz, A., Węgrzyn, A., Oppenheim, A. B., Thomas, M. S. \& Węgrzyn, G. (1997b). Impaired lysogenisation of the Escherichia coli rpoA341 mutant by bacteriophage $\lambda$ is due to the inability of CII to act as a transcriptional activator. Mol Gen Genet 254, 304-311.

Obuchowski, M., Shotland, Y., Koby, S., Giladi, H., Gabig, M., Węgrzyn, G. \& Oppenheim, A. B. (1997c). Stability of CII is a key element in the cold stress response of bacteriophage $\lambda$ infection. J Bacteriol 179, 5987-5991.

Packman, S. \& Sly, S. (1968). Constitutive $\lambda$ DNA replication by $\lambda \mathrm{c} 17$, a regulatory mutant related to virulence. Virology 34 , 778-785.

Pawłowicz, A., Węgrzyn, G. \& Taylor, K. (1993). Effect of coliphage $\lambda P$ gene mutations on the stability of the $\lambda$ O protein, the initiator of $\lambda$ DNA replication. Acta Biochim Pol 40, 29-31.

Ptashne, M. (1992). A Genetic Switch: Phage $\lambda$ and Higher Organisms, 2nd edn. Cambridge, MA: Cell Press/ Blackwell Scientific Publications.

Rosenberg, M., Court, D., Shimatake, H., Brady, C. \& Wulff, D. L. (1978). The relation between function and DNA sequence in an intercistronic regulatory region in phage $\lambda$. Nature 272, 414-423.

Sambrook, J., Fritsch, E. F. \& Maniatis, T. (1989). Molecular Cloning: a Laboratory Manual, 2nd edn. Cold Spring Harbor, NY: Cold Spring Harbor Laboratory.

Soberon, X., Covarrubias, L. \& Bolivar, F. (1980). Construction and characterization of new cloning vehicles. IV. Deletion derivatives of pBR322 and pBR325. Gene 9, 287-305.

Sullivan, S. L. \& Gottesman, M. E. (1992). Requirement for E. coli NusG protein in factor-dependent transcription termination. Cell 68, 989-994.

Szalewska, A., Węgrzyn, G. \& Taylor, K. (1994). Neither absence nor excess of $\lambda \mathrm{O}$ initiator-digesting ClpXP protease affects $\lambda$ plasmid or phage replication in Escherichia coli. Mol Microbiol 13, 469-474.

Szalewska-Pałasz, A. \& Węgrzyn, G. (1994). An additional role of transcriptional activation of ori $\lambda$ in the regulation of $\lambda$ plasmid replication in Escherichia coli. Biochem Biophys Res Commun 205, 802-806.

Szalewska-Pałasz, A., Węgrzyn, A., Herman, A. \& Węgrzyn, G. (1994). The mechanism of the stringent control of $\lambda$ plasmid DNA replication. EMBO J 13, 5779-5785.

Szalewska+Pałasz, A., Wegrzyn, A., Obuchowski, M., Pawłowski, R., Bielawski, K., Thomas, M. S. \& Węgrzyn, G. (1996). Drastically decreased transcription from CII-activated promoters is responsible for impaired lysogenisation of the Escherichia coli rpoA341 mutant by bacteriophage $\lambda$. FEMS Microbiol Lett 144, 21-27. 
SzalewskaPałasz, A., Węgrzyn, A., Błaszczak, A., Taylor, K. \& Węgrzyn, G. (1998). DnaA-stimulated transcriptional activation of orid: Escherichia coli RNA polymerase $\beta$ subunit as a transcriptional activator contact site. Proc Natl Acad Sci USA 95, 4241-4246.

Taylor, K. \& Wegrzyn, G. (1995). Replication of coliphage lambda DNA. FEMS Microbiol Rev 17, 109-119.

Taylor, K. \& Węgrzyn, G. (1998). Regulation of bacteriophage $\lambda$ replication. In Molecular Microbiology, pp. 81-97. Edited by S. J. W. Busby, C. M. Thomas \& N. L. Brown. Berlin \& Heidelberg: Springer.

Thomas, M. S. \& Glass, R. E. (1991). Escherichia coli rpoA mutation which impairs transcription of positively regulated systems. Mol Microbiol 5, 2719-2725.

Węgrzyn, A. \& Węgrzyn, G. (1995). Transcriptional activation of ori $\lambda$ regulates $\lambda$ plasmid replication in amino acid-starved Escherichia coli cells. Biochem Biophys Res Commun 214, 978-984.

Węgrzyn, A., Węgrzyn, G. \& Taylor, K. (1995). Protection of coliphage $\lambda \mathrm{O}$ initiator protein from proteolysis in the assembly of the replication complex in vivo. Virology 207, 179-184.

Węgrzyn, A., Węgrzyn, G., Herman, A. \& Taylor, K. (1996). Protein inheritance: $\lambda$ plasmid replication perpetuated by the heritable replication complex. Genes Cells 1, 953-963.

Wegrzyn, G. (1995). Amplification of $\lambda$ plasmids in Escherichia coli relA mutants. J Biotechnol 43, 139-143.

Wegrzyn, G. \& Taylor, K. (1992). Inheritance of the replication complex by one of two daughter copies during $\lambda$ plasmid replication in Escherichia coli. J Mol Biol 226, 681-688.
Węgrzyn, G., Neubauer, P., Krueger, S., Hecker, M. \& Taylor, K. (1991). Stringent control of replication of plasmids derived from coliphage $\lambda$. Mol Gen Genet 225, 94-98.

Weggrzyn, G., Glass, R. E. \& Thomas, M. S. (1992a). Involvement of the Escherichia coli RNA polymerase $\alpha$ subunit in transcriptional activation by bacteriophage lambda $\mathrm{CI}$ and $\mathrm{CII}$ proteins. Gene 122, 1-7.

Węgrzyn, G., Pawłowicz, A. \& Taylor, K. (1992b). Stability of coliphage $\lambda$ DNA replication initiator, the $\lambda \mathrm{O}$ protein. $J \mathrm{Mol} B i o l$ 226, 675-680.

Węgrzyn, G., Szalewska+Pałasz, A., Węgrzyn, A., Obuchowski, M. \& Taylor, K. (1995a). Transcriptional activation of the origin of coliphage $\lambda$ DNA replication is regulated by the host DnaA initiator function. Gene 154, 47-50.

Węgrzyn, G., Węgrzyn, A., Konieczny, I., Bielawski, K., Konopa, G., Obuchowski, M., Helinski, D. R. \& Taylor, K. (1995b). Involvement of the host initiator function $d n a A$ in the replication of coliphage $\lambda$. Genetics 139, 1469-1481.

Węgrzyn, G., Weggrzyn, A., Pankiewicz, A. \& Taylor, K. (1996). Allele specificity of the Escherichia coli dnaA gene function in the replication of plasmids derived from phage $\lambda$. Mol Gen Genet 252, 580-586.

Wyatt, W. M. \& Inokuchi, H. (1974). Stability of lambda O and P replication functions. Virology 58, 313-315.

Received 24 December 1997; revised 27 April 1998; accepted 14 May 1998. 